\title{
Poor Mothers and Begging: How Impoverished Ethiopian Women Support their Children in the Absence of a Strong State Welfare System
}

\author{
ASHENAFI Hagos Baynesagn (Ph.D.) \\ School of Social Work, College of Social Sciences, Addis Ababa University \\ ETSEGENET Hailu Tolla (MA Gender Studies) \\ Center for Gender Studies, College of Development Studies, Addis Ababa University
}

\begin{abstract}
Despite various efforts to achieve women's empowerment, many women in developing nations still face desperate situations. In countries where social welfare services for the poor do not exist, mothers are expected to support their children by any means possible, including by begging. This is the case in Ethiopia, where poor mothers, especially in urban areas, engage in begging to support their families. To learn more about the lived experiences of these women we conducted qualitative interviews with 18 mother beggars who were identified through purposive sampling. From the interviews, we identified the following reasons for the mothers' begging: gender norms, structural problems, the absence of a strong social welfare system, multiple levels of abuse, and rural-to-urban migration. Children were considered assets as well as burdens by the mother beggars, who believed that more money could be made by using children while acknowledging the stress of looking after their children when begging. Understanding the realities of these situations can help determine suitable responses to the needs of poor mothers raising children in the absence of strong state welfare systems.
\end{abstract}

Keywords: Ethiopia, gender norms, mothers and children, poverty and begging, social welfare 


\section{Introduction}

For poor women who find themselves taking care of their children on their own, one of the easily available options for supporting their families is to engage in begging (Tatek, 2009). Because of religious obligation, many people in Ethiopia give alms and this, consequently, attracts an increasing number of people to engage in begging (Demewozu, 2005). However, being a beggar in Addis Ababa, the capital and largest city in Ethiopia, is not simple. Beggars in the city face various challenges, including difficulties finding a place to live, the risk of arrest and imprisonment, lack of medical care, and the risk of violence from other people living on the streets as well as from community residents.

In Ethiopia, fully $24 \%$ of the population lives in poverty (World Bank, 2020). According to CSA and UNICEF (2018), "some 13 million children are estimated to live in poor households in Ethiopia, two million of whom in extreme poverty" (p.3). Women make up a high proportion of the poorest segment of society. Female-headed families are highly affected by poverty in both urban and rural areas (World Bank, 2020; Dea, 2016; Muleta \& Deressa, 2014). Often poor women engage in the informal sector to make a living. However, many, especially mothers with children, turn to beg to support themselves and their families. Yet, little is known about Ethiopian mothers who are beggars. Thus, this study explored the experiences of mother beggars in Addis Ababa, Ethiopia, to shed light on their situations and identify possible responses. 


\section{Literature Review}

\section{Poverty in Sub-Saharan Africa}

Global poverty is becoming increasingly African (World Bank, 2019). According to the World Bank (2019), although the proportion of the continent's population in extreme poverty declined from $54 \%$ in 1990 to $41 \%$ in 2015 , the absolute number of people living in extreme poverty increased from 278 million to 413 million during that period. And poverty on the continent is particularly acute in Sub-Saharan Africa, which is the poorest region of the world, affected by poverty, malnutrition, and various diseases (Kabuya, 2015). In Sub-Saharan Africa, the rising number of people in absolute poverty adversely affects the region's peace and stability. Although Sub-Saharan African countries are exhibiting positive economic growth, poverty remains the principal developmental challenge (Igbinedion \& Abusomwan, 2014), and many people in Ethiopia are exposed to poverty and lack of basic services (Dercon, Hoddinott, \& Woldehanna, 2012).

In Ethiopia, specifically, and in Africa, more generally, rural and urban poverty reflect different causal factors. In rural Ethiopia, there is a strong association between chronic poverty and distance from towns, lack of physical assets, poor roads, and lack of education (Dercon, Hoddinott, \& Woldehanna, 2012). Alternatively, urban poverty in Ethiopia is often a result of unemployment, under-employment, low wages, and lack of education. Rural to urban migration contributes to an increase in urban poverty, urban congestion, and problems with access to basic services. Rural-urban migration has increased because of civil wars, drought, farmers earn less from agricultural production, and the death of adult providers (Nathan \& Fratkin, 2018). 
Compared to industrialized countries of the global north, welfare services are significantly more limited (or are nonexistent) in developing countries of the global south. Limited welfare services in African countries have aggravated problems of the poor (Igbinedion \& Abusomwan, 2014). In Ethiopia, the government has used safety net programs to support people in poverty (Nathan \& Fratkin, 2018).

The 1996 Developmental Social Welfare Policy, which was revised in 2014 and renamed the Social Protection Policy, is the key policy document regarding welfare in Ethiopia (Lavers, 2016). This policy gives the ultimate responsibility for taking care of the poor to local governments, with the national government playing a coordination role (Lavers, 2016). Efforts started under this policy have included a social insurance program (i.e., pension), a food security program, provision of basic services (i.e., health care), a national nutrition program, support to vulnerable children, health insurance, disaster risk management, support to persons with disabilities, support to older persons, urban housing and grain subsidies, employment promotion, and community-based social support. However, there have been significant challenges in implementing what the government has proposed in the policy document.

In 2005, the Ethiopian government implemented the Productive Safety Net Program (PSNP) (Bahru et al. 2020). The PSNP provides cereals and food oil for beneficiaries after engaging them in different developmental activities in their neighborhood; by 2015, over 10 million people were beneficiaries. Foreign donors are the primary financial supporters of the PSNP, a sign of the Ethiopian government's reliance on foreign aid to support the country's poor (Lavers, 2016). Foreign consultants hired by donors have led the development of the plan to implement the PSNP effort (Lemma \& Cochrane, 2019). The role of non-state actors in supporting the Ethiopian government is significant (Amdissa et al. 2015). Unfortunately, the $4 \mid \mathrm{P}$ a g e 
Ethiopian government's safety net program has been inadequate to address the needs of poor people (Nathan \& Fratkin, 2018).

Absent a strong governmental welfare system, families and charity/non-governmental organizations (NGOs) have assumed much responsibility for assisting those in poverty. Extended family members play a vital role in taking care of others in need (Devereux \& Amddissa Teshome, 2013). Often extended families offer to share their houses and meals with those members who are in a crisis. They also may provide in-kind and monetary support. Besides, there are formal supports offered to people in poverty by religious and non-governmental organizations. Many NGOs operate in Ethiopia and provide basic services, income-generating training, revolving loans, and educational and health-related material supports to people in poverty, especially the poorest of the poor (Devereux \& Amddissa Teshome, 2013). Because Ethiopian investment and developmental activities have left out many of the marginalized and most vulnerable segments of the society (Lemma \& Cochrane, 2019), charity/NGO support for the poor has been invaluable.

\section{Women and Poverty in Ethiopia}

Among the poorest people in Africa, the majority are women and children, largely because of the historical place of women in society. Women in developing African countries, and in Ethiopia, in particular, are often in more desperate economic situations than are men. In Ethiopia, because educational and employment opportunities are limited, preference is given to men, making women's economic situation very challenging, especially in light of the full load of child-rearing responsibilities they bear (Dea, 2016). As Moghadam (2005) suggested: 'if poverty is to be seen as a denial of human rights, it should be recognized that the women among the poor 
suffer doubly from the denial of their human rights-first on account of gender inequality, second on account of poverty' (p.1. ).

According to the World Bank (2020), the percentage of female-headed households in Ethiopia was $25.4 \%$ in 2016, a proportion that has shown only minor variation since 2000 . However, the percentage of female-headed households in rural Ethiopia has increased by more than $10 \%$ since the beginning of the century, rising from $23.5 \%$ in 1999 to $39 \%$ in 2009 (Muleta \& Deressa, 2014).

In both urban and rural areas, female-headed households are more likely to be poor than are those headed by males. In urban Ethiopia in 2004/2005, for example, poverty among femaleheaded households (35.8\%) was higher than among male-headed households $(33.1 \%)$ (Jayamohan \& Kitesa, 2014). In rural Ethiopia, the incidence of poverty is higher among femaleheaded households, and the proportion of poor female-headed households in 2009 was $35.3 \%$. Muleta and Deressa (2014) argued that livestock and land ownership negatively affect the situation of female-headed households in rural Ethiopia.

According to Negesse et al. (2020), 66.1\% of Ethiopian female-headed households experienced food insecurity. Moreover, female-headed households were 1.94 times more likely than male-headed households to develop food insecurity (Negesse et al. 2020). And in urban Ethiopia, housing shortages, limited employment opportunities, and recent development induced displacement further aggravate the problems faced by female-headed households (Megento, 2013).

Housing is one of the most challenging problems of poor people in urban Ethiopia, and women are affected the most. According to Hassan, Grant, and Stevens (2020, p. 477), "multiple 6|P a g e 
intersecting forms of vulnerability - social, economic, and spatial-act as barriers to women in accessing shelter in Hawassa [a city in central Ethiopia]." The number of homeless women and children in Ethiopian cities is increasing (Nathan \& Fratkin, 2018) and their presence on the streets is common (Kaime-Atterhog \& Ahlberg, 2008). Recently it has become possible to find the second generation of homeless families on the streets of Ethiopian cities (Nathan \& Fratkin, 2018).

In Ethiopia, as in other developing countries, poor people dominate the informal economic sector, which is an important income-generating strategy in towns and cities. There is an association between being poor, being a woman, and working in the informal sector, such that most of those engaged in the informal sector are women. However, work in the informal sector often offers very low pay and no benefits or social protections. During an economic downturn, those working in the informal sector are the most affected (Horn, 2010).

Countries that have a large gender gap in various spheres face difficulties in realizing development and prosperity (Dea, 2016). The way the Ethiopian society is organized leaves few ways in which women can contribute to social development. Because of the wide gender gap, using women's potential for political, economic, social, and environmental development is limited (Bayeh, 2016). According to Geleta, et al. (2017), about 90\% of their women who participated in their study indicated that they do not take part in their family decision-making and that family income is mainly controlled by men. As Dea (2016) said about Ethiopian women: "the gender gap is reflected that women are less educated, less paid, highly vulnerable to health risks, unequally represented in politics and highly exposed for violence" (p.33). 
Government initiatives, such as the PSNP, to mitigate poverty have had limited results. Bahru, Jebena, Birner, and Zeller (2020) found "no impact of PSNP on household food security, child dietary diversity, child anthropometric despite and it has a positive impact on increasing child meal frequency" (p.7). Further, despite the PSNP, women's nutritional status remains poor, their chronic energy deficiency continues to be high, and their body mass index has changed little (Irenso \& Atomsa, 2018). The support provided by both government and NGOs has been unable to address the problems of the country's poor, especially women and children in femaleheaded families.

\section{Begging as a Survival Strategy}

Being poor severely limits people's choices for earning a living in a developing country. People who are poor, and who consequently have limited alternatives, may engage in begging to cover their basic needs (Murray, 2013). Chinweuba (2019), for instance, asserted that begging is one means of survival for those who are destitute in Nigeria.

There are several reasons forwarded as to why people engage in begging, but the main one offered is poverty. In Ethiopia, poverty is believed to be the primary reason for begging (Tatek, 2009). According to Asrese, Tilahun, and Mekonnen's (2014) study of begging in Bahir Dar, Ethiopia, poverty, unemployment, and physical disability were identified as the principal reasons for begging. In contrast, Chinweuba (2019) reported that in Nigeria the primary reasons for begging were unemployment, poverty, lack of skills, and unequal economic opportunities.

Not only are different rationales offered for begging, but the legitimacy accorded to begging varies for different population groups within and between countries. For example, black beggars historically were considered as deserved compared to white beggars in South Africa 
(Ndlovu, 2016). In Quito, Ecuador, indigenous people have been considered legitimate beggars, and indigenous mothers are said to migrate with their children from rural villages to beg in the city (Swanson, 2007). In Ethiopia, persons with disabilities and the elderly are commonly seen as legitimate beggars. Persons with disabilities face many challenges, including negative attitudes, unemployment, and lack of access to health facilities (Tefera, Engen, Klink, \& Schippers, 2017). Thus, begging often is their principal means of making a living and, consequently, a significant number of beggars in Ethiopia are persons with disabilities, including mothers (Murray, 2013). Similarly, in the absence of an adequate public or private safety net to support them in their old age, the elderly look for alms and are considered legitimate beggars gave the existing situation.

Although begging may be one of the principal income-earning activities in which poor people are engaged, they are often involved in it because of the lack of alternatives, not out of desire. According to Namwata and Mgabo (2012), in Tanzania, most beggars are not happy about begging and consider it to be an immoral activity. The majority of beggars in Tanzania considered it a temporary activity, although some saw it as a way of life. Child beggars in Addis Ababa, Ethiopia, considered begging as something shameful (Tatek, 2009).

There is an interface between poverty, religion, and begging in Ethiopia (Tatek, 2009). In many religions, giving alms is considered to be respectful and the duty of a religious person (Swanson, 2007). Giving alms to beggars is supported by orthodox Christian teachings and also is a pillar of Islam (Tatek, 2009). Many beggars can be found in Addis Ababa during religious holidays because the number of alms givers (people who give money, food, clothing and other ) is higher than on other days (Demewozu, 2005). The generosity of alms givers can encourage beggars to beg. 
Beggars use different strategies to convince alms givers to give to them. Some of these strategies include stating their problems, using begging songs, telling their stories, and writing notes that describe their problems and need for money (Tatek, 2009). Mentioning their level of poverty and exposing their physical disabilities were found to be among the strategies used by beggars in South Africa (Ndlovu, 2016).

In many countries begging is illegal (Swanson, 2007) and governments have taken different measures to stop begging (Evenett, 2014). The government of Nigeria, for instance, often evacuates beggars from cities, but they re-appear (Chinweuba, 2019). Similarly, in Ecuador, the municipalities often arrested women and children who are engaged in begging (Swanson, 2007).

In Ethiopia, Proclamation No. 384/2004 of January 2004, which replaced the Vagrancy and Vagabondage Proclamation of 1947, considers "a person who is found in a public place or a public utility area or a place open to the public, betting or gambling; and a person is found loitering or prowling at a place, at a time, or in a manner not usual for a law-abiding citizen under circumstances that warrant alarm for the safety of persons or property in a vicinity as a vagrant." Police have used this proclamation to arrest beggars in Addis Ababa during periods of unrest or when big conferences and meetings are being hosted.

Yet despite government actions, the number of beggars continues to increase in many countries. In South Africa, the number of beggars has increased since 1994 (Ndlovu, 2016). There are many beggars in marketplaces and other public spaces in the cities of Nigeria (Chinweuba, 2019). The same is true in Ethiopia; the number of beggars has increased over time, especially in the country's cities (Asrese, Tilahun, \& Mekonnen, 2014). Begging is generally 
more common in urban than in rural areas (Mgabo, 2012). Cities afford beggars a degree of anonymity as well as access to a reasonable number of potential alms givers (Evenett, 2014). There is a concern, however, that the concentration of beggars in cities can damage the image of Ethiopian society (Tatek, 2009).

Although there have been a few investigations of women beggars in Ethiopia, significant gaps in our knowledge remain. A study conducted in South Ethiopia found that most women beggars were aged 25-34 (45.2\%), were not married (47.4\%) and had an average of 2.5 children. Fully $42.6 \%$ said they had not had any protection against forced sex while spending their night on the street. (Alemu et al. 2019). A study conducted in Bahir Dar, a city in the country's Amhara region, reported that most of the women beggars were 20-29 years old (40.4\%). Among the mother beggars who took part in the study, 39.1\% had a history of rape, $54.3 \%$ had their first pregnancy before the age of 18, and 54.7\% experienced an unwanted pregnancy (Engdaw, 2020).

\section{Method}

We used a descriptive qualitative research approach in this study to explore how mother beggars provide support to their children. Descriptive qualitative research emphasizes the provision of wide-ranging, descriptive summaries (Colorafi \& Evans, 2016) that remain close to the data (Sandelowski, 2000). As such, the approach was very useful in allowing us to depict the experiences of Ethiopian mother beggars.

Specifically, we conducted qualitative interviews to collect data. The qualitative interview guide asked about the participants' life stories, including how they became beggars, their opportunities and challenges, a typical day for their child/children, what type of support they provide to their children, and their future aspirations. Probes were used to elicit more detailed information. 
We used purposive sampling to select participants for the interviews. There were two selection criteria: 1) being a beggar for a minimum of two years and 2) having a child/children with them while begging. We initially communicated with 31 women beggars at three churches in Addis Ababa during a religious celebration day. Of the 31 women beggars contacted, 22 had children under their care and had engaged in begging for at least two years. After we reviewed the nature of the study and their rights as participants with them, 18 of the 22 mother beggars said they would be willing to take part in the study. Four of the 22 potential participants subsequently changed their minds and did not complete the interview, saying they did not see the value of sharing their stories and were not comfortable talking about their child/children. Thus, our analysis was based on the responses of 18 mother beggars.

Before beginning the interview we informed each participant about the purpose and contribution of the research. We also told the participant about her right to withdraw from the interview at any point as well as to not respond to particular questions. This helped the participant to decide whether or not to take part in the interview.

After securing a participant's consent to participate in the study, we scheduled a time and location for the interview at the convenience of the participant. We conducted eleven interviews on church premises and seven on street corners. All of the interviews were conducted in Amharic, a language common to and well-known by all of the participants. The second author, who is a woman, conducted all of the interviews.

Interviews lasted approximately 45 to 60 minutes. Interviews were voice recorded with the participant's permission. In three cases participants were not comfortable with voice recording the interviews; in these instances, the second author took notes during the interviews. Immediately following each interview she drafted a memo to document what she observed. 
We locked all the data in a drawer in the first author's office. Throughout the research report, pseudonyms have been used to mask participants' identities. The School of Social Work provided ethical clearance on behalf of Addis Ababa University.

Upon its completion, each interview was transcribed and translated from Amharic to English. We checked each other's translations to ensure accuracy. If there was ambiguity about the meaning of statements, the second author went back and consulted with the relevant participant, who could be located fairly easily because the mother beggars had common areas where each usually begged.

Once all of the interviews were transcribed and translated, we began our analysis by manually combining and synthesizing the collected data into meaningful patterns and themes. We classified the data according to the type of information and brought similar stories together, so it was easier to categorize them into specific subjects and related themes. The first author developed the initial themes, which were then revised and reviewed by the second author. Then, as Colorafi and Evans (2016) suggested, we brought related themes together to create major themes. The major themes we identified are: begging as a better option, begging as a solution for a crisis, begging as a family identity, and challenges for mother beggars and their children. 


\section{Findings}

\section{Respondents' Background}

This study analyzed the responses of 18 mother beggars. The age of participants ranged from 25 to 62 years (mean 38.2). These women had been engaged in begging for a minimum of six months and a maximum of 31 years (mean 7.8 years). They had between one and three children (mean 2.4). The three women over the age of 57 cared for their grandchildren or relatives' children.

\section{Begging as a Better Option}

The mothers in this study did not become beggars without first trying different incomegenerating alternatives. Yet finding work that could accommodate their needs as a single parent and provide an income sufficient to support their families proved to be very challenging.

Being a housemaid was one of the jobs commonly available to women who have limited skills, experience, or education. However, even with few requirements, some of the mothers were not be considered eligible for the job. Aleganesh reported:

Initially, I was trying to be a housemaid or a babysitter but because of my eye crying continuously I do not know the reason and I could not afford to go to the clinic to be checked. It makes me undesirable by the people who want to have a housemaid or a babysitter.

Some of the mother beggars were denied employment as a housemaid because they had their children with them. This happened to Asnakech:

I met with one woman who was willing to have me and she took me to her home and then gave food for me and my son. Therefore, I faced no more problems when 
I arrived and I stayed for two days with her. Within these two days, she told me I could take my son back if I desired to work with her and I felt sad. Hence, I had to leave her home and started this activity.

Abebech, who had five years' experience as a housemaid, could not find this kind of work when she had her son with her. She had a very negative attitude towards families who employed women as a housemaid. She said it had been very difficult to be a housemaid even when her child was not with her. She said of her experience:

Even though I was employed as a housemaid all I got was the food, they said they could not pay me as I have yet to learn how to work. So they feed me and I work for them: it was only food for work. I served them that way for five years before I got to another house at a salary of Birr 25/month.

Although the Ethiopian government has devised income-generating activities to try to alleviate the problems of its citizens, officials have admitted that people make more money begging than as a daily laborer. Many of the women beggars agreed. Further, they reported that begging does not demand physical effort. They also said it was possible to get something to eat from begging, without the need for cooking.

The mother beggars reported earning between 20 birrs (bad days) and 200 birrs (good days) per day, which is better than daily laborers' average pay of 70 birrs per day. And this does not include what is earned by their children begging, which is often the same amount as their mothers' or a little less if they are begging nearby under their mothers' supervision. Hence, the amount earned each day may be doubled or tripled what is presented above depending on the 
number of children who were begging. And these earning do not take into account the in-kind benefits of begging, such as donations of food and clothes.

Because residents of Addis Ababa are accustomed to giving alms as part of their religious values, many of the mother beggars believed that being a beggar was a good alternative, particularly considering how much money they could make each day. Yeju indicated:

Currently, I beg together with my daughters. Begging has an advantage because relatively I earn a good deal of alms both in cash and kind. My children are the source of income. In most of the cases, starting from morning up to the night they beg. I don't like begging since I am involved in it because of my bad economic status. At the same time, I don't have any other alternative than to keep on begging. But I don’t know exactly for how long I will continue living with begging.

\section{Begging as a Solution for a Crisis}

There have been many crises in both rural and urban areas of Ethiopia. Harmful traditional practices such as early marriage, which continues to exist despite efforts to eliminate it, and early life experiences can create fertile grounds for crises. Beletu, for example, left her rural village since she could not live with her older husband which she was forced to marry him at the age of 12. When she arrived in Addis Ababa, she found out about her pregnancy.

A mother often has the primary responsibility for the care of the children during the marriage. If the marriage is dissolved, the burden of taking care of children typically falls solely to the mother, who now may lack whatever financial, practical, and emotional support was formerly provided by her husband. Findings themselves facing the crisis of single parenthood, 
some of the mothers interviewed said they started begging to fulfill their children's basic needs. Senait explained:

I came here five years ago with my two kids because of the death of my husband. My husband was a farmer, and he does not have his land. He farmed for the owner of the land and they used to divide the product equally. Because of this after the death of my husband I had had nothing to feed my kids.

Similarly, Alganesh, a middle-aged woman born and raised in a rural area, said she met her first husband and the father of her first daughter through an arranged marriage. After several years she and her family left the rural area because her husband had a new job offer in a nearby town. Alganesh's only responsibility during that time was to raise her child. Life was relatively easy for her but then her husband became sick and died. Without other relatives to go to for help, she left that town and moved to Addis Ababa to a friend's place to find a job. Soon after arriving, however, she was advised that her friend could not help the family and that she should look for other alternatives. Thus, she ends up begging since she could not find other alternatives.

For some, begging was seen as a solution to a crisis. For example, in Ethiopia's history drought has been a common threat. Many are displaced and forced to leave their place of origin either temporarily or permanently. Nigist's comments illustrate the impact draughts can have on people's lives. She explained her situation, and her view of begging, as follows:

I am from Tigray [a region in the north of the country]. I came with my family [children and husband] to Addis Ababa nine months ago. We came here because of the drought in cereal production. There was a lack of rain in our area. We have four 
hectares of land which we use for cereal production. All of us are begging here in Addis Ababa and saving some money to re-establish our life once again.

Marital abuse is another reality that mothers may experience. When husbands use alcohol or drug, abuse can become very serious. The tragic irony is that if the abuser leaves, which can increase safety, the mother and children may be deprived of the family's key income earner. Meseret indicated:

I never used to live here in Addis Ababa until I recently moved from my hometown, Debre Markos [a city in the Amhara region], trying to get away from my husband who got drunk daily and threatened to take my life. One day I got up, telling no one, and came to Addis Ababa in search of a better life for me and my kids. The challenges I faced when coming here were indescribable and horrific. Sometimes I and my children could eat nothing, not even a loaf of bread. All this happened to us since I had no relatives or family to help me out. Because I had no contact with anyone, begging was the only thing I could do; the only way to feed myself and two of my kids.

Samira's story exemplifies how multiple layers of abuse can damage an individual's life. Samira's parents' living condition was very poor during her early childhood. Unfortunately, her parents' marriage did not last long. Because of lingering impoverished conditions, and disagreement over family matters, Samira's parents divorced. Samira's father remarried and started a new life. Since her mother could not satisfy her needs, her father took Samira to live with him and her stepmother. Samira reported that although she worked hard and took care of everything in the household, her stepmother took her for granted, showed her no gratitude, and 
abused her. Because of the continuing abuse by her stepmother and the fact that she wanted to improve her living situation, Samira, informing no one, left and came to Addis Ababa to find opportunities to change her life. She found work as a housemaid and devoted her entire time to that work. Yet the same thing she experienced when she was with her stepmother happened again. The owners of the house in which she was working abused and sexually harassed her. This led her to make the difficult decision to leave her position and turn to beg

\section{Begging as a Family Identity}

According to the mother beggars, both the mother and her child/children engaged in begging can consider it is a family duty. When they begin begging, children usually spend their time under their mothers' supervision and they are expected to immediately turn over to her any money they earn. Being accompanied by children can increase what the mothers can earn begging; over time, if the children beg on their own, they may even surpass their mothers' earnings. Nigist reported:

I make more money when I have my kid with me. Sometimes people give us money separately and mostly for one of us. In the beginning, my child was frustrated to engage in begging, however, now she is better than me. She understood this is our fate as a family.

Merto, arrived in Addis Ababa over three decades ago hoping to obtain medical care. Unfortunately, by the time she sought treatment, it was too late to save her vision. Having arrived in Addis Ababa with the hope she instead found herself going blind. Since she arrived in the city she has supported herself and her family by begging. With her children now grown, she has begun to bring youngsters from her birthplace to stay with her. She required the children to 
assist her with begging or said she would send them back. Merto said that begging was not a bad thing; it was how she helped her children to grow up.

On Christian holidays mother beggars and their children may position themselves at different corners of a church or they may go to different churches and meet up in the evening. Senait said:

My children know what to do. Surprisingly, three of them are born within five years. That is a blessing for me. They are helping me at their level best. On monthly religious celebration days, we make more money by going our separate ways. So far my children are giving all the money they make to me so it is up to me how much can they spend per day.

Children are expected to do their regular duties in addition to engaging in begging. As Aychesh explained, children share what the mother has, or does not have as the case may be. When there was something to eat in the house her children would have breakfast; if not they just went out with an empty stomach. Aychesh's son would take his mother and his niece to churches where there was a monthly religious celebration. If the church was too far, he might just take them to the taxi or bus station. He would then return home and go to school. Once at the church, Aychesh and her granddaughter would take a seat near the gate and beg alms from people. The girl played with other children or by herself near her grandmother; in the afternoon she might sleep. If people brought food to the church, Aychesh and her granddaughter might have a meal. If they were not offered a meal, they might buy some leftover food from a nearby restaurant or individual seller. 


\section{Challenges for Mother Beggars and their Children}

Because begging is considered to be a socially undesirable activity, there are places where beggars, including mother beggars, were not be allowed to beg. Guards and police officers sometimes forced mother beggars to leave their place of begging. Especially if there were certain events in the city or international people visiting, mother beggars could be forced to leave their usual begging sites. Yeju indicated:

There are police officers and guards who consider us as garbage. They think we are the ones who make the city ugly. Therefore, sometimes they hit us in front of our children. We are not considered citizens.

Adding to the mother beggars' tribulations are youngsters in the neighborhood who would steal and snatch their property. Sometimes the mothers gave these youths money to leave them alone. Meseret explained:

There are youngsters in this neighborhood who makes our life difficult regularly. They think we have money. Sometimes they ask us to give them money for 'chat' and a cigarette. In other times they will take it from us forcefully. It is very difficult to deal with them. Since they are born and grown up here, they think they own everything.

One of the main problems faced by mother beggars was finding a place for their families to stay at night. Because they did not have safe sleeping places, they often were exposed to different abuses. For example, Meseret indicated that: 
We don't have the luxury of choosing a place to spend a night. I choose a place that seems relatively safe, and sometimes people are kind enough to give us some clothes which keep us warm at night. We sleep in different places including a bus station and most of the time at the church.

The mothers whose families lived on the street in plastic shelters expressed a particular fear that their children might be sexually abused. Meseret stated:

Here you can see that many young girls get raped and become pregnant at an early age. It is good that I am living in a rental house even if it is dirty. Even if I am living in rental houses, I always pray that God keeps my children out of such incidents.

Yet even securing rental housing was not necessarily a solution. Aychesh, for example, lived in a very narrow single room. According to her, the house was very old and in very poor condition. She said she was frightened by the thought the house would fall down like a house of cards. As she further explained:

When the rain comes, staying outside the room is better than staying inside. We fear that it would fall apart on us. All the rain gets inside. If it is heavy, there will be flooding in the compound and inside our house. It is meant not to be rented or for people to live in it.

Mother beggars admitted that it was very difficult to properly feed their children while begging. Children were forced to eat whatever they could get through begging. Sometimes, if they did not get food, they might be allowed to buy something like bread. Senait said: 
I have never treated my children as children. I always focused on begging and sometimes I forget them. This sometimes makes me sick. I cry about their fate. If they hadn't been born from me their life might be better. Sometimes I forget to give them even food, let alone clothing and other things.

Not surprisingly, children quickly learned how to survive on the streets. They also might learn socially undesirable behaviors from their peers. This upset and frustrated the mothers. Fearing for their children's future, some wished that their children would not grow up. Samira said:

I am afraid that my child is growing every day. I wish he would remain like this forever. I have seen many children grow up here with us and join street gangs. Some of them are in the street since they had been engaged in criminal activities.

Maintaining personal hygiene was another problem for the mother beggars as their access to clean water was limited. They may not have had time to take care of their or their children's hygiene, and begging did not require it. As Zinashwork described:

Our children contract different diseases very easily since we spend our days around garbage. Individual offenders come to our place and urinate. We also do not keep our hygiene very well since we are beggars. Look at me.

Both mother beggars and their children were often sick. Their living situations and their exposure to unhygienic conditions likely increased their vulnerability to various illnesses. When children got sick, the mothers would seek free medication from public clinics. At times they 
might be asked to buy the drugs from pharmacies, but often could not afford the medication. So they would simply wait for the child to recover. Zinashwork explained:

One of my children gets sick regularly. For the first time, I took him to the public clinic. However, they have asked me to bring a support letter from the Woreda (lower administrative unit). During that time I beg them and cried a lot. Finally, they have agreed to check him. However, they ordered me to buy expensive medication which I didn't buy. Finally, she became ok. However, since then she gets sick so often.

Violence was another of the trials faced by the mother beggars. These women were not only abused by strangers when they slept on the streets, but also by relatives and acquaintances. Senait talked about her boyfriend, who also was a beggar. She believed that he earned more money than she did, but he did not give her any; rather, he demanded that she give him some of what she earned. He drank alcohol, chewed chat, and smoked cigarettes. Sometimes he left for weeks or months. However, when he did spend time with her, they often ended up fighting and she would be seriously beaten.

Poverty and vulnerability led the mother beggars to feel insecure and hopeless. The variation in their daily income deterred them from planning for the future. Some feared what tomorrow might bring. Merto said: "I always feel that I might not have something to eat tomorrow. I don't own any property here. I am living with begging. How can I plan for tomorrow?" Lacking other options, many of the mother beggars felt trapped in begging. 


\section{Discussion}

Even if the percentage declines the number of poor people is increasing in Ethiopia (World Bank, 2020). However, there is no strong social welfare service in place. This makes people look for other alternatives. Hence, having limited alternatives people can end up begging in Ethiopia. People do not jump into begging without considering other options. In particular, mothers who beg resort to it only after exhausting their alternatives. As Ogunkan and Fawole, (2009) stated, begging is a phenomenon in which people engage for survival. The mother beggars' situations show that being a woman and being poor is one of the worst combinations for healthy living.

Currently, the need for housemaids is very high in Addis Ababa. Even though more jobs are becoming available to women in Ethiopia, many are still excluded because of their physical appearance, and/or the need to care for small children. In Ethiopia begging is a structural and societal problem. In this connection, Demewozu (2005) argued that begging was the primary social problem resulting from urbanization in Addis Ababa.

Having strong social ties is one asset in rural Ethiopia that assists people to survive during difficult times. When some people leave their rural homes because of difficult circumstances and come to a new, unfriendly city, there often is no one to turn to for help. Begging becomes the only option available if jobs requiring minimal education or training, such as housemaid work, are unavailable. While being a mother who has a physical disability diminishes one's employment opportunities, having a visible, physical disability is an advantage among beggars as it elicits greater sympathy and results in earning more money. 


\section{Limitations}

This study documented the qualitative accounts of mother beggars, therefore, numerical generalization was not possible. Moreover, the children, who were engaged in begging with their mothers, were not included due to ethical challenges. Only mother beggars who were found in Addis Ababa, Ethiopia were included in this study. We have documented mother beggars' realities based on their experiences.

\section{Implication}

Several structural changes are required, including some form of income assistance especially for people unable to work. In Ethiopia, this would be challenging to implement given the scarcity of resources, and the extreme poverty of many citizens. According to Asrese et al., (2014), begging has psychological consequences. Begging is also a social problem that negatively impacts the surrounding community. This study suggested the need for a strong social welfare system in Ethiopia to decrease the number of people engaged in begging. Otherwise trying to discourage them from using legal measures will not bring significant change.

Further research might be required to analyze the depth of the problem on a wider scale. Comparing the realities of the different parts of Ethiopia might be helpful to come up with comprehensive policy responses. In future studies including the viewpoints of other stakeholders like policymakers, service providers and religious institutes might help to have a better understanding of the situation.

\section{Conclusion}

It is often said that begging is better than stealing. But a lot of Ethiopian women engaged in begging is bleak. When women are solely responsible for child-rearing, are impoverished, and lack welfare state supports, their living conditions can be deplorable. These multifaceted 
problems need to be understood from a gender perspective to provide the required help to mothers and children. This research provides a case example of why social welfare service is required in developing countries like Ethiopia. Social scientists should advocate for mother beggars so that their situations are considered in program and policy planning, development, and implementation. 


\section{References}

Alemu, S., Megabiaw, B., Lette, A., and Ermeko, T., (2019). A survey of contraceptive use and associated factors among street beggar women in South Ethiopia. Journal of Advances in Medicine and Medical Research, 29 (12), 1-11.

DOI:10.9734/JAMMR/2019/v29i1230154

Amdissa, T., Adanech, D., Kasa, T., and Zeleke, T. (2015). Non-state social protection in Ethiopia: Characteristics, governance and policy relevance. Partnership for Africa Social and Governance Research Working Paper No. 003, Nairobi, Kenya.

Asrese, K., Tilahun, T., and Mokonnen, A. (2014). Demographics and socioeconomic determinants of women begging in Bahir Dar, Ethiopia. Humanities and Social Sciences, 2(3), 75-80.

Bahru, B.A., Jebena, M.G., Birner, R., and Zeller, M. (2020). Impact of Ethiopia's productive safety net program on household food security and child nutrition: A marginal structural modeling approach. SSM-Population Health, 12. https//doi.org/10.1016/J.ssmph.2020.100660.

Bayeh, E. (2016). The role of empowering women and achieving gender equality to the sustainable development of Ethiopia. Pacific Science Review B: Humanities and Social Sciences, 2(1), 37-42. https://doi.org/10.1016/j.psrb.2016.09.013

Chinweuba, G.E. (2019). Begging in Nigeria: A critical investigation of its impact on socioeconomic development. IKENGA International Journal of Institute of African Studies UNN, 19 (1), 247-257.

Colorafi, K. J., \& Evans, B. (2016). Qualitative descriptive methods in health science research. HERD. 9(4), 16-25. DOI:10.1177/1937586715614171.

CSA and UNICEF Ethiopia (2018). Multidimensional child deprivation in Ethiopia. First national estimates. Addis Ababa, Ethiopia. Available on the following websites: www.unicef.org/Ethiopia and http://www.csa.gov.et

Demewozu, W. (2005). Begging as a means of livelihood: conferring with the poor at the Orthodox religious ceremonial days in Addis Ababa. Ethiopia African Study Monographs Suppl. 29, 185-191.

Dercon, S., Hoddinott, J., and Woldehanna, T. (2012). Growth and chronic poverty: Evidence from rural communities in Ethiopia. The Journal of Development Studies, 48(2), 238-253. https://doi.org/10.1080/00220388.2011.625410.

Devereux, S. and Amdissa Teshome (2013) From Safety Nets to Social Protection: Options for Direct Support Beneficiaries of the Productive Safety Net Programme. In Food Security, Safety Nets and Social Protection in Ethiopia. Edited by Alula Pankhurst, Dessalegn Rahmato and Gerrit-Jan Van Uffelen, Forum for Social Studies, (pp 69-112), Addis Ababa.

Engdaw, A. (2020). Modern contraceptive utilization and its associated factors among women beggars in Bahir Dar Town, North West Ethiopia. American Journal of Health Research, 8(4), 49-59.

Geleta, E.B., Elabor-Idemudia, P., Henry, C., and Reggassa, N. (2017). The challenges of empowering women: The experience of Pulse Innovation Project in Southern Ethiopia. SAGE open, https://doi.org/10.1177/2158244017736802 
Hassan, F., Grant, E., and Stevens, S. (2010). Understanding shelter from a gender perspective: the case of Hawassa, Ethiopia. Environment \& Urbanization, 32(2): 463-480.

DIO:10.1177/0956247820942109

Horn, Z.E. (2010). The effect of the global economic crisis on women in the informal economy: research findings from WIEGO and the Inclusive Cities Partners. Gender and Development, 18(2), 263-276. DIO:10.1080/13552074.2010.491339.

Igbinedion, S. O., \& Abusomwan, S.O. (2014). Sub-Saharan Africa and the challenges of poverty eradication: Contemporary issues and policy framework. International Journal of Development and Sustainability, 3 (12), 2206-2217.

Irenso, A.A. and Atomsa, G.E. (2018). Implications of Ethiopian Productive Safety Net Programme on household dietary diversity and women's body mass index: a crosssectional study. Food \& Nutrition Research, 62, http//dx.dio.org/10.29219/fnr.v62.1574

Joyamohan, M.K. and Kitesa, A.T. (2014). Gender and poverty - an analysis of urban poverty in Ethiopia, Development Studies Research, 1(1), 233-243. DIO:

10.1080/21665095.2014.917053.

Kabuya, F.I. (2015). Fundamental causes of poverty in Sub-Saharan Africa. Journal of Humanities and Social Science, 20 (6), PP 78-81.

Kaime-Atterhog, W., and Ahlberg, B.M. (2008). Are street children beyond rehabilitation? Understanding the life situation of street boys through ethnographic methods in Nakuru, Kenya, Children and Youth services Review, 30, 1345-1354.

Lavers, T. (2016). Social protection in an aspiring 'developmental state': The political divers of Ethiopia’s PSNP. ESID Working Paper No. 73. Manchester, UK: The University of Manchester. Available at www.effective-states.org.

Lemma, M.D. and Cochrane, L. (2019). Policy coherence and social protection in Ethiopia: Ensuring no one is left behind. Societies, 9. Dio.10.3390/soc9010019.

Megento, T. (2013). Inner-city housing and urban development-induced displacement: impact on poor female-headed households in Arada sub city of Addis Ababa, Ethiopia, Journal of Sustainable Development in Africa, Clarion University of Pennsylvania, USA, Vol.15, No.2, PP: 131-141.

Moghadam, V. M. (2005). Globalizing Women: Transnational feminist networks. Baltimore and London: The Johns Hopkins University Press. 251 Pages

Mulatu Dea (2016). The prospectus, challenges, and causes of gender disparity and its implication for Ethiopia's development: Qualitative inquiry. Journal of Education and Practice, 7(4).

Muleta, A.N., and Deressa, D.F. (2014). Female headed households and poverty in rural Ethiopia. Science, Technology and Arts Research Journal, 3 (1), 152-155. DOI: http://dx.doi.org/10.4314/star.v3i1.25

Murray, N. G. (2013). Disabled Beggars in Addis Ababa, Ethiopia. Geneva: International Labor Office.

Namwata, B. and Mgabo, M.R. (2012). Feelings of beggars on begging life and their survival livelihoods in urban areas of central Tanzania. IJPSS, 2 (7).

Nathan, M.A., and Fratkin, E. (2018). The lives of street women and children in Hawassa, Ethiopia. African Studies Review, 61(1), 158-184. http://dio.org/10.1017/asr.2017.135.

Ndlovu, T. (2016). All poor together? Race and the stylistics of begging at traffic lights in Johannesburg. Critical Arts projects \& unisa press, 30(4): 126-141. DIO:10.1080/02560046.2016.1226765 
Negesse, A., Jara, D., Temesegen, H., Dessie, G., Getaneh, T., Mulugeta, H., Abebaw, Z., Taddege, T., Wagnew, F., and Negesse, Y. (2020). The impact of being of the female gender for household head on the prevalence of food insecurity in Ethiopia: A systematicreview and meta-analysis. Public Health reviews, 41(15). https://doi.org/10.1186/s40985$\underline{020-00131-8}$

Sandelowski, M. (2000). Whatever happened to qualitative description? Research in Nursing \& Health, 3(4), 234-340. DOI:10.1002/1098-240X(200008)23:4<334::AIDNUR9>3.0.CO;2-G

Swanson, K. (2007). 'Bad Mothers' and 'delinquent Children': Unravelling anti-begging rhetoric in the Ecuadorian Andes, Gender, Place and Culture, 14(6), 703-720. DIO:10.1080/09663690701659150.

Tatek, A. (2009) Begging as a livelihood pathway of street children in Addis Ababa, Forum for Development Studies, 36:2, 275-300. DIO:10.1080/08039410.2009.9666438

Tefera, B., Engen, M. V., Klink J. V., \& Schippers, A. (2017). The grace of motherhood: Disabled women contending with societal denial of intimacy, pregnancy, and motherhood in Ethiopia, Disability \& Society, 32 (10), 1510-1533, DOI: $10.1080 / 09687599.2017 .1361385$

World Bank (2020). Ethiopia poverty assessment: Poverty rate declines, despite challenges. Retrieved on December 2020 from https://www.worldbank.org/en/country/ethiopia/publication/ethiopia-poverty-assessmentpoverty-rate-declines-despite-challenges

World Bank, (2019). Accelerating poverty reduction in Africa: In five charts. October 9, 2019. Accessed in April 2020 from https://www.worldbank.org/en/region/afr/publication/accelerating-poverty-reduction-inafrica-in-five-charts 